\title{
Interactive Learning Multimedia Improving Learning Motivation Elementary School Students
}

\author{
Fariz Budiarto $^{1}$, Akhmad Jazuli ${ }^{2}$ \\ \{ farizhheroscout@gmail.com ${ }^{1}, \underline{\text { akhmadjazuli.ump@gmail.com }}{ }^{2}$ \} \\ Magister Pendidikan Dasar, Universitas Muhammadiyah Purwokerto
}

\begin{abstract}
Elementary school students need learning media as an effort to concretize learning material that is still abstract. This study uses a literature review to discuss interactive learning multimedia to increase students' motivation to learn science in elementary schools. The research method uses the Systematic Literature Review method. Data was collected by documenting and analyzing articles that matched the research topics published in 2015-2020. This study uses 15 articles sourced from accredited national journals. The research articles were obtained through the Publish or Perish 7 application sourced from the Google Scholar database. The results showed that interactive multimedia helps students understand the learning material, attracts students' interest in learning, and makes the learning process more interactive. Interactive learning multimedia could increase students' motivation to learn science in elementary schools.
\end{abstract}

Keywords: interactive multimedia, learning motivation, science, elementary school

\section{Introduction}

The rapid development of information and communication technology has brought significant changes to the world of education. As an essential part of education, the curriculum must adapt to technology and civilization to equip students to live and develop amid technological developments. Teachers as curriculum implementers must design and implement creative and innovative learning by integrating technology in learning. The need for technology-based learning in the form of multimedia continues to increase along with the progress and development of technology and information that is increasing rapidly [1]. One form of technology application in learning is through the use of interactive learning multimedia.

Learning multimedia innovation requires learning to foster more dynamic, intuitive, and quality learning [2]. Interactive learning multimedia is a learning medium that incorporates different components of text, pictures, photographs, sound, video, and animation [3] [4] [5] [6]. Another essential element of interactive learning multimedia is navigation and interactivity. Navigation in learning multimedia facilitates users to manage the direction of learning and supports good interaction between users and learning multimedia [6] [7]. Interactive learning multimedia also has a controller component that students can use to regulate and control the running of interactive multimedia so that students have flexibility in the learning process [2] [6]. 
Previous research has revealed various benefits of learning multimedia, including increasing learning motivation [8] [9], helping students to understand learning materials better [7] [10], and having an impact on improving learning outcomes and contributing to improving the quality of learning [11] [12]. In addition, interactive learning multimedia can also accommodate student learning styles both visually, audio, and kinetically [13]. Through the desired learning style according to the needs of these students, it is hoped that students will be happier and motivated so that it is easy to understand the learning material. Thus, students will find it easier to understand the learning material presented.

\section{Methods}

This literature review research uses the Systematic Literature Review (SLR) method. There are five stages in carrying out a literature review, namely: formulating research questions, searching for articles, evaluating articles, summarizing articles, interpreting article findings [14]. Systematic Literature Review (SLR) identifies, reviews, evaluates, and analyzes all available research. With this method, the researcher reviews and identifies journals in a structured manner following predetermined steps [15]. Researchers collected journal articles on the Google Scholar database with the help of the Publish or Perish 7 application. The keywords used in the articles were: multimedia interactive learning, learning motivation, science, and elementary school. The articles collected are only articles published in the period 2015 to 2020. From various articles, the researchers selected 15 articles from an accredited national journal that are closely related to the keywords used. In the next step, the researcher classifies articles related to interactive learning multimedia, science learning, motivation, and learning outcomes in general. The articles' metadata is tabulated in a table that includes the author's name, the year published, the journal's name, and results. After that, the researcher reviewed and analyzed the article in-depth, especially regarding the research results presented in the discussion and conclusion sections. At the end of the study, the researcher compared the findings presented in the article and concluded.

\section{Results and Discussion}

Interactive multimedia in the learning process becomes a demand and a need for technology and information-based learning. Interactive learning multimedia supports practical, interactive, and fun learning for students [2]. The learning process's quality and the expected learning objectives can be achieved more optimally through interactive multimedia. The following are the research results on using and utilizing interactive learning multimedia in science learning for students at the elementary school level presented in Table 1.

Table 1. Research Results on the Use of Interactive Learning Multimedia

\begin{tabular}{|c|c|c|}
\hline Author, Year & Journal & Research Result \\
\hline $\begin{array}{l}\text { Muhammad } \\
\text { Saifudin, } \\
\text { Agus Wedi. (2020) }\end{array}$ & $\begin{array}{l}\text { Jurnal Kajian } \\
\text { Teknologi } \\
\text { Pendidikan }\end{array}$ & $\begin{array}{l}\text { Interactive learning multimedia can } \\
\text { help students understand learning } \\
\text { materials so that they can increase } \\
\text { student motivation and learning } \\
\text { outcomes }\end{array}$ \\
\hline $\begin{array}{lr}\text { Ikha Nur Jannah, } & \text { Dwi } \\
\text { Prasetiyawati } & \text { Diyah } \\
\text { Hariyanti, Singgih } & \text { Adhi } \\
\text { Prasetyo. (2020) } & \end{array}$ & $\begin{array}{l}\text { Jurnal Ilmiah } \\
\text { Sekolah Dasar }\end{array}$ & $\begin{array}{l}\text { Interactive learning multimedia make } \\
\text { it easier for students to understand the } \\
\text { learning material and is effective in } \\
\text { improving the science learning process } \\
\text { and outcomes }\end{array}$ \\
\hline
\end{tabular}




\begin{tabular}{|c|c|c|}
\hline $\begin{array}{l}\text { Ratih Wulandari, Herawati } \\
\text { Susilo, Dedi Kuswandi. } \\
\text { (2017) }\end{array}$ & $\begin{array}{c}\text { Jurnal } \\
\text { Pendidikan: } \\
\text { Teori, } \\
\text { Penelitian, dan } \\
\text { Pengembangan }\end{array}$ & $\begin{array}{l}\text { Interactive learning multimedia can } \\
\text { attract student interest and attention so } \\
\text { that it can increase student activity and } \\
\text { learning outcomes }\end{array}$ \\
\hline Taufiq Nuril Akbar. (2016) & $\begin{array}{c}\text { Jurnal } \\
\text { Pendidikan: } \\
\text { Teori, } \\
\text { Penelitian, dan } \\
\text { Pengembangan }\end{array}$ & $\begin{array}{l}\text { Interactive learning multimedia will } \\
\text { make students feel happy and } \\
\text { motivated in learning so that it can } \\
\text { improve student learning outcomes }\end{array}$ \\
\hline $\begin{array}{l}\text { Hayumuti, Herawati Susilo, } \\
\text { Susriyati Manahal. (2016) }\end{array}$ & $\begin{array}{c}\text { Jurnal } \\
\text { Pendidikan: } \\
\text { Teori, } \\
\text { Penelitian, dan } \\
\text { Pengembangan } \\
\end{array}$ & $\begin{array}{l}\text { Interactive learning multimedia can } \\
\text { foster enthusiasm and motivation for } \\
\text { student learning so that it can increase } \\
\text { student activity and learning outcomes }\end{array}$ \\
\hline Galuh Kartikasari. (2016) & $\begin{array}{l}\text { Jurnal Dinamika } \\
\text { Penelitian: } \\
\text { Media } \\
\text { Komunikasi } \\
\text { Penelitian Sosial } \\
\text { Keagamaan } \\
\end{array}$ & $\begin{array}{l}\text { Interactive learning multimedia is } \\
\text { effective for increasing students' } \\
\text { motivation and learning outcomes }\end{array}$ \\
\hline Naniek Kusumawati. (2016) & $\begin{array}{c}\text { Jurnal } \\
\text { Pendidikan } \\
\text { Dasar dan } \\
\text { Pembelajaran }\end{array}$ & $\begin{array}{l}\text { Interactive learning multimedia can } \\
\text { increase student interest, activity, and } \\
\text { learning outcomes }\end{array}$ \\
\hline 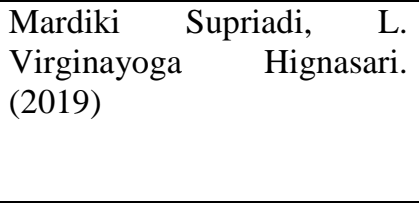 & $\begin{array}{c}\text { Jurnal } \\
\text { Teknologi } \\
\text { Pendidikan }\end{array}$ & $\begin{array}{l}\text { Interactive learning multimedia helps } \\
\text { students understand concepts and } \\
\text { learning materials so that they have an } \\
\text { impact on improving student learning } \\
\text { outcomes }\end{array}$ \\
\hline $\begin{array}{l}\text { Fachrur Rozie, dan Andika } \\
\text { Adinanda Siswoyo. (2015) }\end{array}$ & Jurnal Rekayasa & $\begin{array}{l}\text { Interactive learning multimedia is very } \\
\text { helpful for making students motivated } \\
\text { to learn }\end{array}$ \\
\hline $\begin{array}{lr}\text { Dian Oktafiani, } & \text { Lukman } \\
\text { Nulhakim, } & \text { Trian } \\
\text { Pamungkas } & \text { Alamsyah. } \\
(2020) & \end{array}$ & $\begin{array}{l}\text { Jurnal Mimbar } \\
\text { PGSD }\end{array}$ & $\begin{array}{l}\text { Interactive learning multimedia can } \\
\text { improve learning completeness and } \\
\text { increase understanding so that it } \\
\text { contributes to improving learning } \\
\text { outcomes and fosters positive } \\
\text { interactions in the form of student } \\
\text { interest and motivation in learning }\end{array}$ \\
\hline $\begin{array}{l}\text { Asep Sukenda Egok, Tri } \\
\text { Juli Hajani. (2018) }\end{array}$ & $\begin{array}{c}\text { Journal of } \\
\text { Elementary } \\
\text { School (JOES) }\end{array}$ & $\begin{array}{lcr}\text { Interactive } & \text { learning } & \text { multimedia } \\
\text { contributes positively to improving } \\
\text { student learning outcomes }\end{array}$ \\
\hline 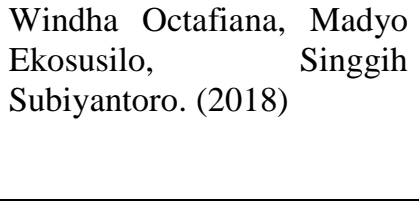 & $\begin{array}{l}\text { Jurnal } \\
\text { Komunikasi } \\
\text { Pendidikan }\end{array}$ & $\begin{array}{l}\text { Interactive learning multimedia can } \\
\text { make students interested and help } \\
\text { students understand the subject matter } \\
\text { to increase motivation and learning } \\
\text { outcomes }\end{array}$ \\
\hline
\end{tabular}




\begin{tabular}{lll}
\hline Gede Cris Smaramanik & Jurnal Edutech & $\begin{array}{l}\text { Interactive learning multimedia in the } \\
\text { Dwiqi, I Gde Wawan }\end{array}$ \\
$\begin{array}{l}\text { Sudatha, Adrianus I Wayan } \\
\text { Ilia Yuda Sukmana. (2020) }\end{array}$ & $\begin{array}{l}\text { learning process is very effective in } \\
\text { attracting students' interest in learning } \\
\text { and learning to be more interactive so } \\
\text { that it can significantly improve } \\
\text { student learning outcomes }\end{array}$ \\
\hline $\begin{array}{l}\text { Berlina Wulandari, Fiqri Jurnal Krea-TIF } \\
\text { Ardiansyah, Puspa Eosina, }\end{array}$ & $\begin{array}{l}\text { Interactive learning multimedia can } \\
\text { help students understand learning }\end{array}$ \\
Hersanto Fajri. (2019) & $\begin{array}{l}\text { materials, build students learning } \\
\text { enthusiasm and improve student } \\
\text { learning outcomes }\end{array}$ \\
\hline $\begin{array}{l}\text { Nukke Deliany, Asep Jurnal Educare } \\
\text { Hidayat, Yeti Nurhayati. }\end{array}$ & $\begin{array}{l}\text { Interactive learning multimedia can } \\
\text { improve conceptual understanding so } \\
\text { t2019) }\end{array}$ & $\begin{array}{l}\text { that it has an impact on increasing } \\
\text { student learning outcomes }\end{array}$ \\
\hline
\end{tabular}

Based on the results of research that have been carried out as listed in Table 1, the use and utilization of interactive learning multimedia in science learning can make it easier for teachers to deliver learning material and make it easier for students to understand learning material, so that it can improve student learning outcomes [16]. Learning can be more flexible with interactive learning multimedia, because students can study anywhere and anytime. In addition, multimedia can make students active in the learning process. Interactive learning multimedia is effective in improving student learning processes and activities, so that it has an impact on the acquisition of more optimal student learning outcomes [17] [18] [22] [26].

Students' various learning styles and learning speeds can be accommodated through interactive learning multimedia [8]. The use of interactive multimedia in learning will lead students to learn independently. The teacher's help as a learning facilitator will help students achieve the learning objectives determined. The results showed that the use of interactive multimedia could make students feel happy and motivated in learning, so that it can increase motivation and student learning outcomes [19] [20] [21], foster motivation, interest, and good enthusiasm for learning [20] [24] [ 25] [27] [28]. In addition, interactive learning multimedia can make it easier for students to understand the concepts and learning materials [23] [27] [29] [30], so that the use of interactive learning multimedia can improve student learning outcomes more optimally.

The research results also prove that interactive multimedia can improve understanding of concepts in science learning, because it can concretize concepts classified as abstract. However, it is important to note by a teacher that teachers must bring students to do logical reasoning by applying the material to concrete examples. Teachers must remember that elementary school-aged children are still in the concrete operational stage and cannot yet imagine abstract learning materials. This action aligns with Piaget's cognitive theory, which states that children at elementary school can think logically as long as these thoughts can be applied to concrete examples.

Learning using interactive multimedia will build active student involvement during the learning process to create effective learning. Learning becomes more fun for students, because they can interact directly with the learning media they use. Learning to be fun occurs, because multimedia has valuable interactivity for being actively involved in the learning process by using multimedia [32]. Thus, the activities and involvement of students in the learning process will be more optimal thanks to the use of interactive multimedia in the learning process. 
Learning using interactive multimedia attracts students more attention, is more effective and efficient, more practical, and students more absorb the material, because it is by student learning modalities [33]. This explanation is proven through the results of the research that has been done. The results also show that multimedia can create practical and efficient learning in achieving learning objectives. This fact can be proven by increasing students' motivation and learning outcomes after using interactive multimedia in the learning process.

Interactive learning multimedia has an attractive appearance and contains various interactive media to create a memorable learning experience. The results show that interactive multimedia makes students motivated and enthusiastic about learning and builds a fun learning atmosphere. The results of this study support previous research, which concluded that the use of interactive multimedia in learning provides a fun and meaningful learning experience for students [34]. The use of interactive multimedia in learning is one of the efforts to increase students' interest and motivation in learning and learning outcomes that are less than optimal due to the dominance of teachers with the lecture method and the use of media that are less interactive with students.

\section{Conclusion}

Interactive learning multimedia in science learning, especially for elementary school students, can help students understand the materials and concepts of science learning materials, foster attention, desire, and interest in learning. With these benefits, interactive learning multimedia increases student learning motivation, impacting achieving optimal learning outcomes. In addition, interactive learning multimedia support effective, efficient, fun learning and make students more enthusiastic in participating in learning activities.

\section{References}

[1] Ampa AT, Rasyid MA, Rahman MA, Haryanto H, Muhammad Basri D. The implementation of multimedia learning materials in teaching English speaking skills. International Journal of English Language Education. 2013;1(3):293.

[2] Ariyani N, Haryanto D. Pembelajaran Multimedia di Sekolah: Pedoman Pembelajaran Inspiratif, Konstruktif, dan Prospektif. Jakarta: Restasi Pustaka. 2010.

[3] Philips R. The developer's handbook to interactive multimedia: a practical guide for educational applications. New York: Kogan Page, Ltd. https://doi. org/10.1. 1997;1:7898.

[4] Terentyeva IV, Pugacheva NB, Luchinina AO, Khalmetov TA, Safin NM, Shaydullina AN. Selection and Structuring of Training Multimedia Educational Materials for University Students: Practical Recommendations. International Journal of Instruction. 2019 Jul;12(3):759-80.

[5] Wibawanto W, Ds SS. Desain dan pemrograman multimedia pembelajaran interaktif. Cerdas Ulet Kreatif Publisher; 2017 Jan 27..

[6] Munir. (2015). Multimedia: Konseo dan Aplikasi dalam Pendidikan. Alfabeta

[7] Gunawardhana LK, Palaniappan S. Using multimedia as an education tool. In9th Annual International Conference on Computer Games, Multimedia and Allied Technology (CGAT 2016). doi 2016 (Vol. 10).

[8] Leow FT, Neo M. Interactive multimedia learning: Innovating classroom education in a Malaysian university. Turkish Online Journal of Educational Technology-TOJET. 2014 Apr;13(2):99-110.

[9] Rajendra IM, Sudana IM. The influence of interactive multimedia technology to enhance achievement students on practice skills in mechanical technology. InJournal of Physics: Conference Series 2018 (Vol. 953, No. 1, p. 012104). IOP Publishing.

[10] Wu, T. J., \& Tai, Y. N. Effects of multimedia information technology integrated Multi-Sensory instruction on students' learning motivation and outcome. Eurasia Journal of Mathematics, Science and Technology Education, 2016;. 12(4), 1065-1074. https://doi.org/10.12973/eurasia.2016.1552a 
[11] Neo M, Neo TK, Yap WL. Students' perceptions of interactive multimedia mediated web-based learning: A Malaysian perspective. InProceedings of ASCILITE 2008 Conference, Melbourne 2008 Nov..

[12] Nusir S, Alsmadi I, Al-Kabi M, Sharadgah F. Studying the impact of using multimedia interactive programs on children's ability to learn basic math skills. E-learning and Digital Media. 2013 Sep;10(3):305-19.

[13] Ismaniati, C.. Penggunaan Teknologi Informasi dan Komunikasi Dalam Peningkatan Kualitas Pembelajaran. 2010; Universitas Negeri Yogyakarta.

[14] Khan KS, Kunz R, Kleijnen J, Antes G. Five steps to conducting a systematic review. Journal of the royal society of medicine. 2003 Mar;96(3):118-21.

[15] Triandini E, Jayanatha S, Indrawan A, Putra GW, Iswara B. Metode Systematic Literature Review untuk Identifikasi Platform dan Metode Pengembangan Sistem Informasi di Indonesia. Indonesian Journal of Information Systems. 2019 Feb 23;1(2):63-77.

[16] Saifudin MF, Susilaningsih S, Wedi A. Pengembangan Multimedia Interaktif Materi Sumber Energi untuk Memudahkan Belajar Siswa SD. JKTP: Jurnal Kajian Teknologi Pendidikan. 2020 Feb 10;3(1):68-77.

[17] Jannah IN. Efektivitas Penggunaan Multimedia dalam Pembelajaran IPA di SD. Jurnal Ilmiah Sekolah Dasar. 2020 Apr 2;4(1):54-9.

[18] Wulandari R, Susilo H, Kuswandi D. Penggunaan multimedia interaktif bermuatan game edukasi untuk meningkatkan aktivitas dan hasil belajar siswa sekolah dasar. Jurnal Pendidikan: Teori, Penelitian, dan Pengembangan. 2017 Aug 1;2(8):1024-9.

[19] Akbar TN. Pengembangan multimedia interaktif IPA berorientasi guided inquiry pada materi sistem pernapasan manusia kelas V SDN Kebonsari 3 Malang. Jurnal Pendidikan: Teori, Penelitian, dan Pengembangan. 2016 Jun 1;1(6):1120-6.

[20] Hayumuti H, Susilo H, Manahal S. Penggunaan multimedia CD Interaktif dalam peningkatan aktivitas dan hasil belajar IPA tema selalu berhemat energi di kelas IV SDN Klanderan KEDIRI. Jurnal Pendidikan: Teori, Penelitian, dan Pengembangan. 2016 Jul 1;1(7):1437-41.

[21] Kartikasari G. Pengaruh media pembelajaran berbasis multimedia terhadap motivasi dan hasil belajar materi sistem pencernaan manusia: Studi eksperimen pada siswa kelas V MI Miftahul Huda Pandantoyo. Dinamika Penelitian: Media Komunikasi Penelitian Sosial Keagamaan. 2016 Jul 3;16(1):59-77.

[22] Kusumawati N. Pengembangan media pembelajaran IPA Dengan animasi macromedia flash berbasis model pengajaran langsung (direct instruction) di Sekolah Dasar. Premiere Educandum: Jurnal Pendidikan Dasar dan Pembelajaran. 2016 Nov 15;5(02).

[23] Supriadi M, Hignasari LV. Pengembangan media virtual reality pada muatan pelajaran IPA Kelas VI Sekolah Dasar. JTP-Jurnal Teknologi Pendidikan. 2019 Dec 31;21(3):241-55.

[24] Rozie F, Siswoyo AA. Pengembangan Media Pembelajaran Ipa Interaktif Materi Tata Surya di SDN Banyuajuh Kamal Madura. Rekayasa. 2015 Oct 1;8(2):129.

[25] Oktafiani D, Nulhakim L, Alamsyah TP. Pengembangan media pembelajaran IPA berbasis multimedia interaktif menggunakan Adobe Flash pada Kelas IV. Mimbar PGSD Undiksha. 2020 Oct 28;8(3):527-40.

[26] Egok AS, Hajani TJ. Pengembangan Multimedia Interaktif pada Pembelajaran IPA bagi Siswa Sekolah Dasar Kota Lubuklinggau. Journal of Elementary School (JOES). 2018 Dec 30;1(2):14157.

[27] Octafiana, W., Ekosusilo, M., \& Subiyantoro, S. (2018). Pengembangan Multimedia Interaktif Pada Materi Pesawat Sederhana Untuk Siswa Sekolah Dasar. Jurnal komunikasi pendidikan, 2(2), 168-175. http://dx.doi.org/10.32832/kreatif.v7i1.2028

[28] Dwiqi GC, Sudatha IG, Sukmana AI. Pengembangan multimedia pembelajaran interaktif mata pelajaran IPA untuk siswa SD kelas V. Jurnal Edutech Undiksha. 2020 Sep 30;8(2):33-48.

[29] Wulandari B, Ardiansyah F, Eosina P, Fajri H. Media Pembelajaran Interaktif Ipa Untuk Sekolah Dasar Berbasis Multimedia. Krea-TIF. 2019 May 16;7(1):11-9.

[30] Deliany N, Hidayat A, Nurhayati Y. Penerapan Multimedia Interaktif untuk Meningkatkan Pemahaman Konsep IPA Peserta Didik di Sekolah Dasar. Educare. 2019 Dec 31:90-7. 
[31] Miftah, M. (2013). Fungsi dan Peran Media Pembelajaran Sebagai Upaya Peningkatan Kemampuan Belajar. Kwangsan: Jurnal Teknologi Pendidikan, 1(2), 95-105. https://doi.org/10.31800/jtp.kw.v1n2.p95--105

[32] Cairncross S, Mannion M. Interactive multimedia and learning: Realizing the benefits. Innovations in education and teaching international. 2001 Jan 1;38(2):156-64.

[33] Musfiqon, H. M. Pengembangan Media dan Sumber Pembelajaran. (2012). Prestasi Pustakaraya

[34] Wiana W, Barliana MS, Riyanto AA. The Effectiveness of Using Interactive Multimedia Based on Motion Graphic in Concept Mastering Enhancement and Fashion Designing Skill in Digital Format. International Journal of Emerging Technologies in Learning. 2018 Feb 1;13(2). 